\title{
Modern Benthic Foraminiferal Diversity: An Initial Insight into the Total Foraminiferal Diversity along the Kuwait Coastal Water
}

\author{
Eqbal Al-Enezi ${ }^{1}$, Sawsan Khader ${ }^{2}$, Eszter Balassi ${ }^{3}$ and Fabrizio Frontalini ${ }^{3, * \mathbb{D}}$ \\ Kuwait Institute for Scientific Research, Safat 13109, Kuwait; eenezi@kisr.edu.kw \\ 2 Department of Earth and Environmental Sciences, Faculty of Science, Kuwait University, \\ Safat 13060, Kuwait; eihabs90@gmail.com \\ 3 Department of Pure and Applied Sciences (DiSPeA), Urbino University, 61029 Urbino, Italy; \\ balassieszti@gmail.com \\ * Correspondence: fabrizio.frontalini@uniurb.it; Tel.: +39-392-8457-666
}

Received: 11 March 2020; Accepted: 2 April 2020; Published: 5 April 2020

\begin{abstract}
Kuwait territorial water hosts an important part of national biodiversity (i.e., zooplankton and phytoplankton), but very limited information exists on the overall diversity of benthic foraminifera. On the basis of the integration of publications, reports and theses with new available data from the Kuwait Bay and the northern islands, this study infers the total benthic foraminiferal diversity within Kuwait territorial water. This new literature survey documents the presence of 451 species belonging to 156 genera, 64 families, 31 superfamilies and 9 orders. These values are relatively high in consideration of the limited extension and the shallow depth of the Kuwait territorial water. Kuwait waters offer a variety of different environments and sub-environments (low salinity/muddy areas in the northern part, embayment, rocky tidal flats, coral reef systems, islands and shelf slope) that all together host largely diversified benthic foraminiferal communities. These figures are herein considered as underestimated because of the grouping of unassigned species due to the lack of reference collections and materials, as well as the neglection of the soft-shell monothalamids ('allogromiids').
\end{abstract}

Keywords: benthic foraminifera; biodiversity; checklist; Kuwait; Arabian Gulf

\section{Introduction}

Checklists, lists of species, represent the baseline for the implementation of natural conservation biodiversity plans and are important inventories for wildlife management, species protection and biogeographical studies. Such inventories become even more essential in the context of global climatic change and in areas with a high degree of endemism or in those threatened by pollution.

In this context, the Arabian Gulf, an extension of the Indian Ocean, is known for the largest reservoirs of petroleum, as well as for its unique oceanographical conditions and endemic biota adapted to extreme conditions. This area has a strategic value under economic and environmental perspectives [1]. The Gulf represents the hottest marine environment and has been commonly used as a model for the 2100 climate change in tropical oceans [2]. The rapid economic development and antropogenization of the Gulf coupled with the peculiar climatic features of the region and the relatively shallow and reduced size of the basin have led to a deterioration of natural habitats [3]. In light of the present global climatic changes, an increasing of sea surface temperature (SST) of $\sim 2.2^{\circ} \mathrm{C}$ by 2100 has been recently predicted for the Gulf [4]. The same authors inferred the highest differences of mean annual warming between 2100 and 2015 along the north coast of the United Arab Emirates, the southern coastlines of the Strait of Hormuz and the northernmost part of the Gulf including Kuwait. 
The Kuwait territorial waters host an important part of the national biodiversity and are also nursery grounds for a number of species [5]. A total of 235 macrofaunal taxa in the intertidal zone [6], over 340 zooplankton and phytoplankton species [7], 345 species of fish [8] and 105 species of marine plants have been recorded from Kuwait waters. Specifically, 55 tintinnid species [9]; 80 flagellate species, including benthic dinoflagellate, phototropic flagellates and euglenoids [10]; and 37 copepods species [11] were described in Kuwait. Detailed investigations on the overall diversity of phytoplankton species were provided by [7], with the identification of more than 140 diatoms, 55 dinoflagellates, 2 coccolithophorids and a cyanophyte species. The phytoplankton checklist was then updated with the recognition of over 323 species, including diatoms (202 species), dinoflagellates (108 species), silicoflagellates, naked flagellates and cyanophytes [12]. Several groups of marine organisms, including fish, are relatively well-known because of their commercial value, whereas a large number of invertebrates thriving in the benthos has been poorly considered and commonly neglected. Despite this, these invertebrates have both an ecological and a conservation relevance, as well as a scientific one.

Among them, benthic foraminifera are single-celled organisms living in a wide range of marine environments [13]. They are inferred to play a major role in the biogeochemical cycles [14] and occupy a low trophic position in the food web [15]. A limited number of foraminiferal studies has covered extensive geographical areas [16-22], and the regional-synoptic approach documenting benthic foraminiferal diversity is currently quite limited [19]. Although benthic foraminifera have been largely studied in the Arabian Gulf [23-27], a limited knowledge of their diversity exists for the Kuwait coastal water [28], as most of the available studies have focused on their application as bioindicators [29,30].

In light of this, the main objective of the present paper is to provide a checklist of recent benthic foraminiferal species and to infer the total biodiversity of this group of organisms in the Kuwait coastal marine areas on the basis of the available dataset published in the last fifty years, coupled with original data.

\section{Geography, Hydrology and Study Area}

The State of Kuwait lies in the northeastern part of the Arabian Peninsula, between latitudes $28^{\circ} 30^{\prime}$ and $30^{\circ} 05^{\prime} \mathrm{N}$ and longitudes $46^{\circ} 33^{\prime}$ and $48^{\circ} 30^{\prime} \mathrm{E}$. The country is bordered by Iraq on the northwest, Saudi Arabia on the south and southwest, and the Arabian Gulf on the east. The total area, considering the three larger (Bubiyan, Failaka and Warba) and the six smaller (Miskan, Auha, Umm Al-Namil, Kubbar, Qaruh and Umm Al-Maradim) islands, covers about 17,818 $\mathrm{km}^{2}$ [31]. The coastal length of Kuwait, including islands, is about $500 \mathrm{~km}$, which represents about $7611 \mathrm{~km}^{2}$ of the Kuwaiti territorial water [31]. The marine environment is situated in a transitional zone between two major geomorphic units of the northern part of the Arabian Gulf, the stable Arabian Foreland in the west and southwest, and the compound Shatt al-Arab Delta of the Mesopotamian Plain in the north. As a result, the influence of these two geomorphic units is reflected in the marine and coastal environments of the country. On the basis of environmental characteristics, the Kuwaiti coastal area can be broadly divided into northern and southern provinces. The northern province, which includes Khor Al-Sabiya, Kuwait Bay and the six northern coastal and offshore islands (Warba, Bubiyan, Miskan, Failaka, Auha and Umm Al-Namil), is characterized by extensive mudflats that are covered by a mixture of fine sand, silt and clay, bounded landward by extensive sabkhas and encrusted with algae and very rich in organisms [32]. Its clastic deposits are commonly derived from the Shatt al-Arab, the principal riverine input in the Gulf $[33,34]$. This river contributes to the cyclonic circulation, promotes the productivity by the discharge of nutrients and forms a plume in the northwestern part of the Gulf (i.e., Kuwait). The deflection of the Shatt al-Arab river plume due to the Coriolis effect affects the sedimentary influx in the northern area but excludes most of the Iranian coast [35]. The southern coastal province located between the coastal area of Kuwait City and the southern border with Saudi Arabia is marked by extensive rocky tidal flats masked by a relatively thick cover of sand and bounded landward by several oolitic ridges and inland sabkha flats. Coral reef systems, including platforms, patch reefs and fringing corals, are abundant in the southern area, particularly around the islands [7]. 
The offshore area of Kuwait is characterized by shallow depths that generally increase in a southeasterly direction, reaching a maximum depth of about $30 \mathrm{~m}$. Currents along the Kuwaiti shores are generally parallel to the coast. The main hydrodynamic factors affecting Kuwait coastal areas are tidal currents and waves. Along the Kuwait coast, tides have a mean range of about $3 \mathrm{~m}$ (mesotidal) and are semidiurnal (with two highs and two lows) to mixed type in the north and diurnal toward south. During spring tides, tidal currents reach $0.5-0.6 \mathrm{~m} / \mathrm{s}$, with a maximum of $1 \mathrm{~m} / \mathrm{s}$ at the entrance of the Kuwait Bay [7]. The shallow nature of the offshore area in general and the northern sector, in particular, limits the generation of large waves along the shoreline. Waves higher than $50 \mathrm{~cm}$ are rare in the northern offshore area of Kuwait. The northern coastal area is generally marked by a low-energy environment, with the currents being the prime source of energy. Currents seem to be more active along Khor Al-Sabiya, carrying tidal sediment to the deeper parts of Kuwait waters. Very extreme conditions characterize the Kuwait seawaters, with SST difference between summer and winter exceeding $20^{\circ} \mathrm{C}$, with the summer temperature reaching $36^{\circ} \mathrm{C}$ and salinity over 45 [7]. The Kuwait Bay is eutrophicated and influenced by runoff, sewage discharge and several anthropogenic activities. All of these characteristics make the Kuwait water a very harsh environment for marine communities.

Five physiographic regions have been identified in Kuwait: (1) the submerged estuarine flat (shallow muddy area); (2) the submerged estuarine channel and bar system; (3) the Kuwait Bay trough; (4) the shelf slope; and (5) the islands [7,36]. The submerged estuarine flat lies off the northern coast of Kuwait and includes most of the Kuwait Bay and the area surrounding three northern islands (Failaka, Auha and Miskan Islands).

The climate of Kuwait is affected by the desert climate that is dry and hot. The annual air temperature varies between a maximum of $50{ }^{\circ} \mathrm{C}$ in summer and a minimum of $0{ }^{\circ} \mathrm{C}$ in winter. Precipitation is scarce $(<10 \mathrm{~cm} / \mathrm{yr})$ and makes a negligible contribution to the freshwater budget of the Arabian Gulf. Estimates of evaporation vary from 140 to $500 \mathrm{~cm} / \mathrm{yr}$ [37]. In addition to the effects of high temperatures in summer, high evaporation rates and low rain falls, winds have a pronounced influence on the oceanographic and sedimentological nature of the area. The most dominant wind direction in the Arabian Gulf is the "Shamal", a NW wind that blows the year around, and is usually associated with dust storms. The wind brings large quantities of terrigenous materials to the Kuwait's offshore zone [32].

On the basis of the above, several environments characterized by specific organisms (biotopes) were defined, such as shallow sand/mud (less than $5 \mathrm{~m}$ ), deep sand/mud (over $5 \mathrm{~m}$ ), coral reef, rock/algae, seagrass and productive intertidal mud/sand flats [38].

\section{Previous Benthic Foraminiferal Studies within the Kuwaiti Territorial Waters}

Several papers, theses and reports-the latter mainly from the Kuwait Institute of Scientific Research (KISR) - have been published on benthic foraminifera within Kuwait territorial waters from the late 1960s [23,28-30,39-59] (Figure 1). 


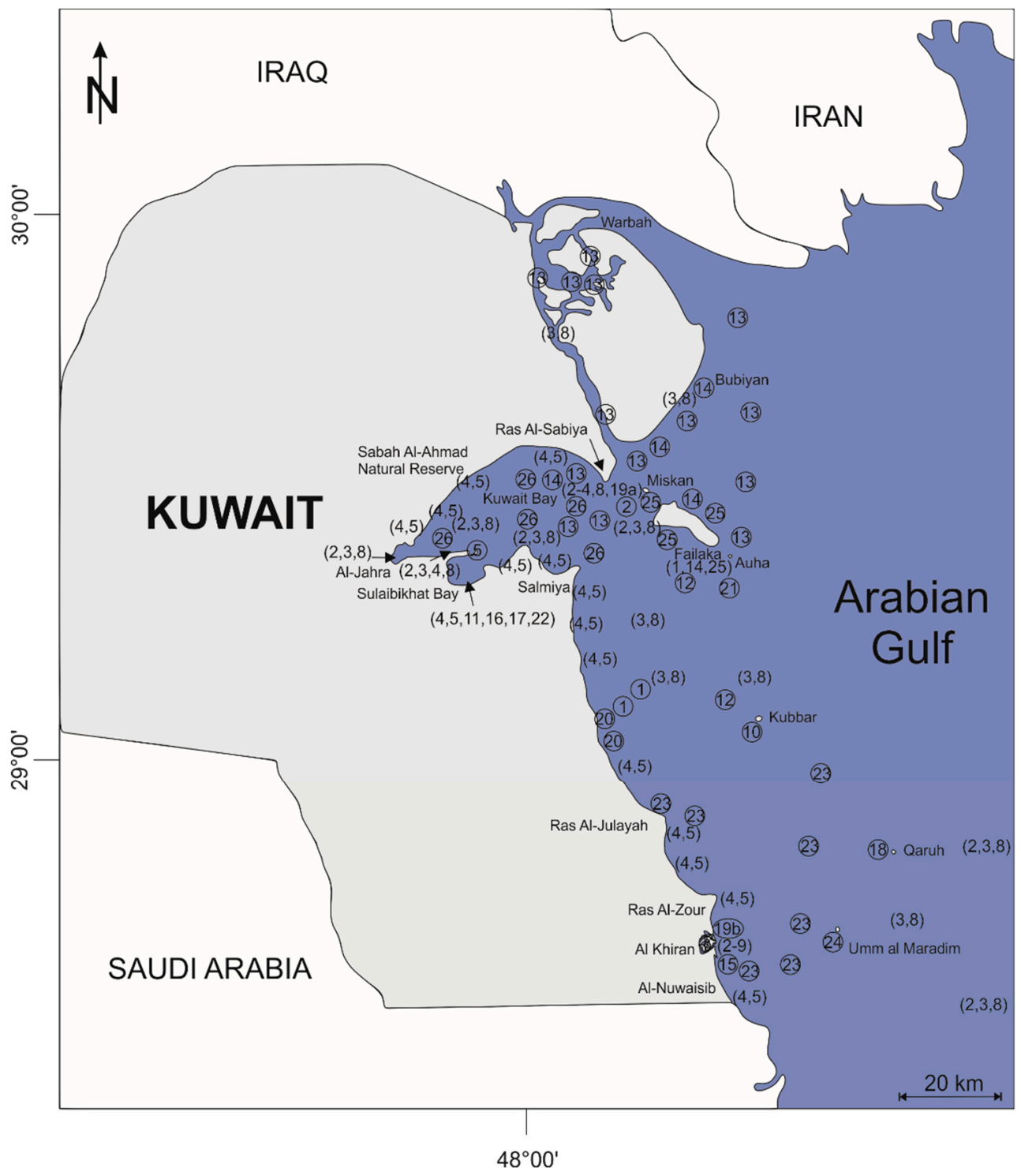

Figure 1. Location map of the Kuwait territorial waters, showing the geographical location of the investigated areas (numbers are organized by date of publication). (1) Mina Al-Ahmadi and south of Failaka Island [39]; (2) offshore area of Kuwait [40]; (3) Kuwait shoreline and the offshore area between Kuwait and Saudi Arabia [41]; (4) tidal flats from Al-Sabiya to Al-Nuwaisib, including the Sulaibikhat Bay and reefal flats of Umm Al-Namil Island and Al-Akaz [42]; (5) tidal flats from Al-Sabiya to Al-Nuwaisib, including the Sulaibikhat Bay and reefal flats of Umm Al-Namil Island and Al-Akaz [43]; (6) Khor Al-Nhaim lagoon in the Al-Khiran area [44]; (7) Al-Khiran area [45]; (8) Kuwait shoreline and the offshore area between Kuwait and Saudi Arabia [46]; (9) tidal and intertidal channels within two connected creeks (Khor Al-Mufateh and Khor Al-Mamlaha) in the Al-Khiran area [47]; (10) Kubbar Island [48]; (11) the Sulaibikhat Bay [49]; (12) offshore area of central Kuwait [23]; (13) the Shatt al-Arab Delta [50]; (14) the Western Bubiyan area and the surrounding of three islands (Failaka, Auha and Miskan) [51]; (15) Khor Iskandar, close to Al-Khiran area [52]; (16) Shuwaikh area [53]; (17) the Sulaibikhat Bay [29]; (18) Qaruh Island [54]; (19a) Ras Al-Subiya and (19b) Ras Al-Zour [55]; (20) Mina Ahmadi and Mina Abdullah [56]; (21) south of Failaka Island [57]; (22) the Sulaibikhat Bay [30]; (23) carbonate ramp transect in the southern part of Kuwait [58]; (24) Umm al Maradim Island [28]; (25) Auha, Failaka and Miskan Islands [59]; (26) Kuwait Bay: present study.

To the best of our knowledge, the first investigation of benthic foraminifera in Kuwait was carried out by [39], who identified 73 species in offshore areas around Mina Al-Ahmadi and south 
of Failaka Island (1 in Figure 1). A total of 120 foraminiferal species of which 100 benthic ones was recognized by [40] in the offshore area of Kuwait (2 in Figure 1). Later on, twelve localities along the Kuwait shoreline and in the offshore area between Kuwait and Saudi Arabia led to the identification of 208 species and the definition of seven new species [41] (3 in Figure 1). The relationship between sedimentology and benthic ecology (i.e., Ostracoda and foraminifera) was investigated by [42]. The authors identified 120 benthic foraminiferal species belonging to 50 genera; however, the complete list of the identified species was not provided (4 in Figure 1). The marine benthic microfauna, including benthic foraminifera, was documented in tidal flat localities from Al-Sabiya to Al-Nuwaisib, including the Sulaibikhat Bay and reefal flats of Umm Al-Namil Island and Al-Akaz [43]. Foraminifera were found to be the most abundant organisms among microfauna in the Sulaibikhat Bay, but the recognized benthic foraminiferal taxa were not provided (5 in Figure 1). A great abundance of Peneroplis distinctiva described as Cribrospirolina distinctiva from the small Khor Al-Nhaim Lagoon in the Al-Khiran area was identified by [44] (6 in Figure 1). The area around Al-Khiran was extensively sampled in 1984-1985, with the collection of 180 stations and the ostracod and foraminiferal microfauna were investigated [45]. They suggested a foraminiferal fauna typical of stress environments and identified 35 taxa (7 in Figure 1). On the basis of an extensive sampling (250 stations) in Kuwait's marine environments, coupled with the available materials [41], the distribution of 60 common benthic foraminiferal species was documented (8 in Figure 1) [46]. Forty-two benthic foraminiferal species were recognized in the total assemblages (living plus dead) of the tidal and intertidal channels within two connected creeks (Khor Al-Mufateh and Khor Al-Mamlaha) in the Al-Khiran area [47]. On the basis of the cluster analysis, the authors defined four foraminiferal assemblages, namely dry upper intertidal, wet upper intertidal, middle intertidal and lower tidal-tidal channel reflecting different environmental conditions (9 in Figure 1). The distribution of recent benthic foraminifera around the reefal Kubbar Island was documented by [48]. The benthic foraminifera assemblages were particularly diversified with 81 species, mainly represented by Miliolida and Rotaliida (10 in Figure 1). In order to identify potential bioindicators of pollution, the total benthic foraminiferal assemblages were studied in the Sulaibikhat Bay [49], leading to the recognition of 45 species (11 in Figure 1). An extensive sampling covering the Arabian Gulf led to the identification of 94 species [23]; however, only a few Kuwaiti localities were included (12 in Figure 1). An investigation in the western part of the Shatt al-Arab Delta was performed to study the total (living plus dead) foraminiferal assemblages [50]. In this study, 46 benthic foraminiferal species, mainly represented by Rotaliina, were recognized, and on the basis of the cluster analysis, three assemblages related to salinity conditions and physiographic setting were identified (13 in Figure 1). The potential impact of draining of Iraqi marshes on the sediment quality of Northern Kuwait marine area, including Khor Sabiya (western Bubiyan area), part of the Kuwait Bay and the surrounding of three islands (Failaka, Auha and Miskan), was investigated by [51] (14 in Figure 1). Additionally, 63 benthic foraminiferal species were listed. Khor Iskandar is a coastal inlet located close to the Al-Khiran area and to the border of Saudi Arabia. A total of 60 benthic foraminiferal species were identified in this area that were mainly represented by Rotaliina and Miliolina [52]. The most abundant species were Ammonia sadoensis, Ammonia tepida and Ammonia umbonata (15 in Figure 1). The response of benthic foraminiferal assemblages to the effect of trace elements was investigated in the eastern part of the Sulaibikhat Bay, an area near the Kuwait University in Shuwaikh [53]. The study focused on seasonal sampling in winter and summer on thirty stations and led to the identification of 54 benthic foraminiferal species (16 in Figure 1). A comprehensive investigation of the total benthic foraminifera from the polluted marine environment of the Sulaibikhat Bay was performed by [29], who identified 45 benthic foraminiferal species, of which only one is agglutinated (17 in Figure 1). The distribution of benthic foraminifera around the reefal Qaruh Island during the summer and winter seasons led to the identification of 60 benthic foraminiferal species [54] (18 in Figure 1). Benthic foraminifera were used to study the effects of two thermal pollution plants, namely Ras Al-Subiya (19a in Figure 1) and Ras Al-Zour (19a in Figure 1), and a total of 29 and 39 benthic foraminiferal species were identified, respectively [55]. Environmental baseline data, including data on benthic foraminifera, were gathered 
to check the feasibility to construct an offshore-treated wastewater discharge in Mina Ahmadi and Mina Abdullah refineries [56] (20 in Figure 1). In this technical report, a total of 39 benthic foraminiferal species was identified, and the assemblages were reported to be poorly diversified and characterized by high abnormalities at stations close to the shore line. The distribution, diversity and abundance of benthic foraminifera were studied in the northwestern part of the Arabian Gulf [57]. Unfortunately, as in [23], only one station falls in the Kuwait territorial waters (21 in Figure 1). In a study aimed at evaluating the environmental quality of the Sulaibikhat Bay, a total of fifty-nine benthic foraminiferal taxa were identified in the living assemblages [30]. These taxa were represented by four orders and suborders, Textulariida, Lagenida, Rotaliida and Miliolida, with the latter represented by 40 species (22 in Figure 1). Modern and relict benthic foraminiferal biofacies along a carbonate ramp transect were studied in the southern part of Kuwait [58]. In this study, a total of 141 benthic foraminiferal taxa were identified, a figure that is much higher compared to previous studies (23 in Figure 1). The benthic foraminiferal assemblages were documented around the unique and largest coral island of Kuwait, Umm al Maradim, where overall 101 and 96 species were identified in the total and living assemblages, respectively [28] (24 in Figure 1). In terms of abundance, the porcelaneous wall-type test dominated the foraminiferal assemblages, followed by hyaline and agglutinated ones. The present checklist also accounts for a recent study with the sampling of 50 stations around the three northern islands of Auha, Failaka and Miskan [59], with the recognition of 92 species (25 in Figure 1). Additionally, an extensive sediment sampling with the collection of 46 samples was performed, to study benthic foraminifera in the Kuwait Bay (26 in Figure 1).

\section{Materials and Methods}

A total of 50 samples were collected in May 2008, around the three northern islands (Auha, Failaka and Miskan) (Figure 2a), and 46 samples were collected in November 2018 in the Kuwait Bay (Figure 2b). These extensive surveys were carried out to study the benthic foraminiferal distribution by covering different environments, bathymetric depths and environmental conditions. Surface sediment samples were collected by using a small gravity corer. Only the uppermost part of sediments $(0-1 \mathrm{~cm})$ was taken from each sampling station and immediately stained with rose Bengal dye, to differentiate between living and nonliving specimens. Samples were then oven-dried, weighed and gently washed with tap water, through a $63 \mu \mathrm{m}$ sieve, to remove clay, silt and any excess dye. The so-obtained residues were dried and weighed again. The dried samples were analyzed, using a stereo microscope in the fraction $>125 \mu \mathrm{m}$. The specimens were picked and taxonomically identified, following the generic classifications of [60] and the specific classifications of [61-66], as well as available publications with illustrated specimens from Kuwait [41,46,47,50].

On the basis of the available foraminiferal literature survey (published papers, theses, restricted and open reports), coupled with new data from the three northern islands (Auha, Failaka and Miskan) and the Kuwait Bay, a list of all the identified benthic foraminiferal taxa in the Kuwait territorial waters has been compiled [23,28-30,39-59] (Table 1 and Supplementary Table S1). 


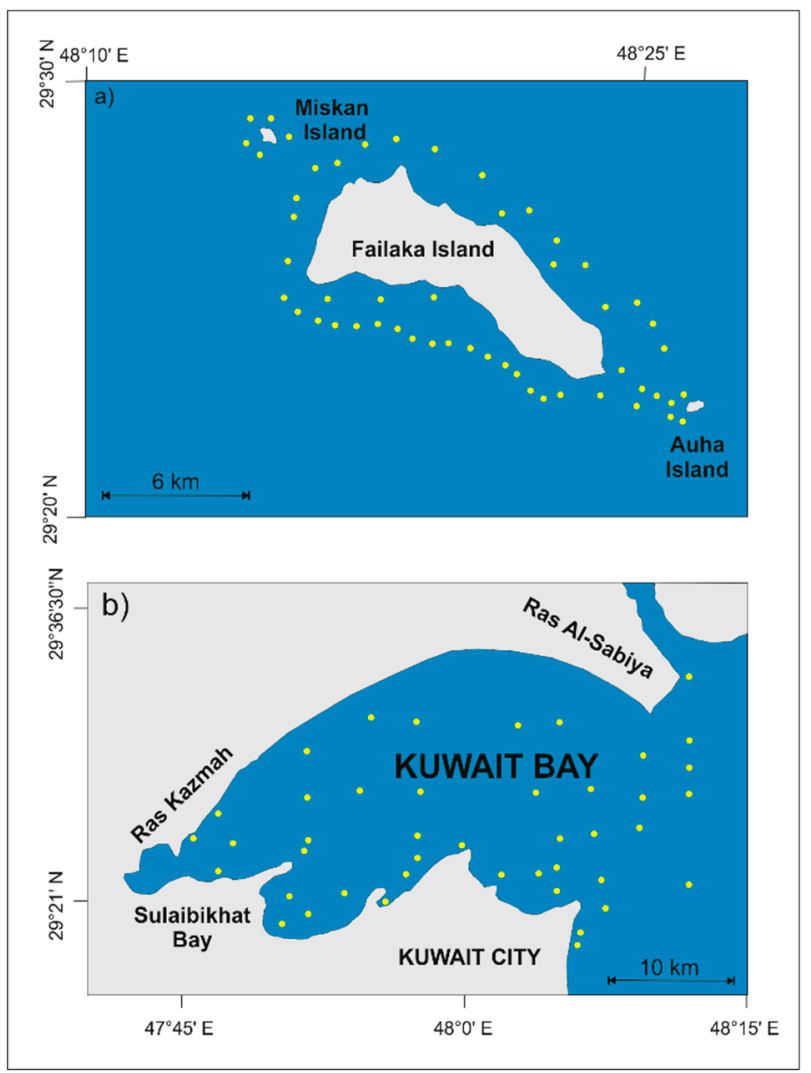

Figure 2. Geographical locations of the stations in this study: (a) around Auha, Failaka and Miskan Islands; and (b) within the Kuwait Bay.

Table 1. Benthic foraminiferal taxa (order, superfamily and family) and number of genera and species recognized in Kuwait territorial waters.

\begin{tabular}{|c|c|c|c|c|}
\hline Order & Superfamily & Family & $\begin{array}{c}\text { Number of } \\
\text { Genera }\end{array}$ & $\begin{array}{c}\text { Number of } \\
\text { Species }\end{array}$ \\
\hline \multirow[t]{4}{*}{ Lituolida } & Lituoloidea & Lituolidae & 3 & 6 \\
\hline & Verneuilinoidea & Prolixoplectidae & 1 & 2 \\
\hline & & Verneuilinidae & 1 & 1 \\
\hline & Trochamminoidea & Trochamminidae & 3 & 3 \\
\hline \multirow[t]{4}{*}{ Textulariida } & Textularioidea & Textulariidae & 4 & 25 \\
\hline & & Olgiidae & 1 & 1 \\
\hline & Eggerelloidea & Valvulinidae & 1 & 1 \\
\hline & Hormosinoidea & Reophacidae & 1 & 1 \\
\hline \multirow[t]{12}{*}{ Miliolida } & Cornuspiroidea & Cornuspiridae & 1 & 1 \\
\hline & Milioloidea & Cribrolinoididae & 1 & 10 \\
\hline & & Hauerinidae & 35 & 165 \\
\hline & & Spiroloculinidae & 1 & 18 \\
\hline & Miliolacea & Riveroinidae & 1 & 1 \\
\hline & Nubecularioidea & Fischerinidae & 2 & 2 \\
\hline & & Ophthalmidiidae & 3 & 7 \\
\hline & & Nubeculariidae & 3 & 3 \\
\hline & Soritoidea & Peneroplidae & 4 & 7 \\
\hline & & Soritidae & 1 & 2 \\
\hline & & Miliamminidae & 1 & 2 \\
\hline & Squamulinoidea & Squamulinidae & 1 & 1 \\
\hline \multirow[t]{2}{*}{ Spirillinida } & & Spirillinidae & 1 & 2 \\
\hline & & Patellinidae & 1 & 1 \\
\hline \multirow[t]{2}{*}{ Lagenida } & Nodosarioidea & Lagenidae & 3 & 17 \\
\hline & & Nodosariidae & 5 & 5 \\
\hline
\end{tabular}


Table 1. Cont.

\begin{tabular}{|c|c|c|c|c|}
\hline Order & Superfamily & Family & $\begin{array}{c}\text { Number of } \\
\text { Genera }\end{array}$ & $\begin{array}{c}\text { Number of } \\
\text { Species }\end{array}$ \\
\hline Vaginulinida & & Vaginulinidae & 1 & 1 \\
\hline Robertinida & Robertinoidea & Robertinidae & 1 & 1 \\
\hline \multirow[t]{35}{*}{ Rotaliida } & Buliminoidea & Buliminidae & 1 & 1 \\
\hline & & Reussellidae & 2 & 6 \\
\hline & & Trimosinidae & 2 & 2 \\
\hline & Cassidulinoidea & Bolivinitidae & 7 & 8 \\
\hline & & Tortoplectellidae & 1 & 1 \\
\hline & & Siphogenerinoididae & 1 & 1 \\
\hline & Chilostomelloidea & Trichohyalidae & 1 & 1 \\
\hline & & Anomalinidae & 1 & 1 \\
\hline & Fursenkoinoidea & Fursenkoinidae & 1 & 2 \\
\hline & Turrilinoidea & Turrilinidae & 1 & 1 \\
\hline & & Stainforthiidae & 2 & 2 \\
\hline & Bolivinoidea & Bolivinidae & 1 & 10 \\
\hline & Discorboidea & Rosalinidae & 3 & 10 \\
\hline & & Eponididae & 2 & 3 \\
\hline & & Cancrisidae & 2 & 3 \\
\hline & & Discorbidae & 1 & 1 \\
\hline & & Heleninidae & 1 & 1 \\
\hline & Discorbinelloidea & Discorbinellidae & 2 & 4 \\
\hline & & Pseudoparrellidae & 1 & 1 \\
\hline & Planorbulinoidea & Cibicididae & 4 & 7 \\
\hline & & Planorbulinidae & 2 & 2 \\
\hline & & Cymbaloporidae & 3 & 6 \\
\hline & Nonionoidea & Nonionidae & 3 & 7 \\
\hline & Glabratelloidea & Glabratellidae & 1 & 1 \\
\hline & Rotalioidea & Elphidiidae & 4 & 21 \\
\hline & & Elphidiellidae & 1 & 1 \\
\hline & & Haynesinidae & 1 & 2 \\
\hline & & Ammoniidae & 6 & 25 \\
\hline & & Notorotaliidae & 1 & 1 \\
\hline & Acervulinoidea & Acervulinidae & 1 & 2 \\
\hline & Asterigerinoidea & Amphisteginidae & 1 & 1 \\
\hline & & Epistomariidae & 1 & 1 \\
\hline & & Asterigerinatidae & 1 & 1 \\
\hline & Nummulitoidea & Nummulitidae & 2 & 6 \\
\hline & Murrayinellidae & Murrayinellidae & 1 & 2 \\
\hline \multirow[t]{3}{*}{ Polymorphinida } & Polymorphinoidea & Glandulinidae & 2 & 3 \\
\hline & & Polymorphinidae & 4 & 6 \\
\hline & & Ellipsolagenidae & 3 & 11 \\
\hline
\end{tabular}

The largest part of these studies has been carried out in the Kuwait Bay [29,30,49,53], around the Al-Khiran area [44,45,47,55], along the Kuwaiti coastline [42,43], whereas only a few of them have focused on the islands $[28,48,54,57,59]$, including the Bubiyan one [50] (Table 1 and Supplementary Table S1).

Most of these publications and reports are based on the total assemblages. The total assemblages combine living and dead foraminifera and include autochthonous taxa, as well as allochthonous ones that might be transported from other localities. To the best of our knowledge, the only studies that have solely considered the living (Rose-Bengal stained) part of benthic foraminifera are $[28,30]$ and the present study in the Kuwait Bay area.

The World Register of Marine Species (WoRMS) [67] was followed for the systematic classification of the benthic foraminiferal species, genera, and the suprageneric taxonomic categories adopted in this 
study. The validity of the species and genera has been checked against WoRMS, and the unassigned specimens (sp.), as reported from different publications, were combined in a general category (spp.).

The presence-absence list of taxa was then used to calculate the $\beta$ diversity or differentiation and $\gamma$ or regional diversity. The $\beta$ diversity was calculated by using the PAST (PAlaeontological STatistics) data analysis package (version 3.05) [68] and is expressed as the Whittaker's original measure ( $\beta w)$ [69], whereas $\gamma$ diversity is calculated as the total species richness in the area. The $\beta \mathrm{w}$ represents the variation in species composition (the highest is the value of $\beta w$, the highest is the difference) and is here used to define the benthic foraminiferal species difference between selected environments within Kuwait, namely the northern islands (Failaka Island, Bubiyan Island and the Shatt al-Arab area), the southern islands (Umm Al-Maradim, Qaruh and Kubbar Islands), the southern coast (Al-Khiran, Khor Iskander and Ras Al-Zour) and the tidal flat and the Kuwait Bay (Supplementary Figure S1). Open nomenclature species (i.e., sp.) are not considered.

\section{Results}

A total of 451 benthic foraminiferal species were identified, represented by $8.9 \%$ agglutinated, $48.5 \%$ porcelaneous and $42.6 \%$ hyaline wall types. These taxa belong to 156 genera, 64 families, 31 superfamilies and 9 orders (Table 1). Here we recognized the following orders: Lituolida, Textulariida, Miliolida, Spirillinida, Lagenida, Vaginulinida, Robertinida, Polymorphinida and Rotaliida (Table 1 and Supplementary Table S1). The Order Allogromiida and the Suborder Globigerinina were not considered in this study, the former because all the considered studies were performed on dried sediment samples that did not allow the preservation of them, while the latter is a planktonic group.

The Order Lituolida is represented by three superfamilies (Lituoloidea, Verneuilinoidea and Trochamminoidea), four families (Lituolidae, Prolixoplectidae, Verneuilinidae and Trochamminidae) and five genera (Ammobaculites, Ammomarginulina, Gaudryina, Trochammina and Rotaliammina) (Table 1 and Supplementary Table S1).

Three superfamilies (Textularioidea, Eggerelloidea and Hormosinoidea), four families (Textulariidae, Olgiidae, Valvulinidae and Reophacidae) and seven genera (Sahulia, Textularia, Siphotextularia, Bigenerina, Olgita, Clavulina and Reophax) were identified within the Order Textulariida (Table 1 and Supplementary Table S1).

The Order Miliolida includes six superfamilies (Cornuspiroidea, Milioloidea, Miliolacea, Nubecularioidea, Soritoidea and Squamulinoidea), 12 families (Cornuspiridae, Cribrolinoididae, Hauerinidae, Spiroloculinidae, Riveroinidae, Fischerinidae, Ophthalmidiidae, Nubeculariidae, Peneroplidae, Soritidae, Miliamminidae and Squamulinidae) and 54 genera (Cornuspira, Adelosina, Flintinoides, Hauerina, Sigmoihauerina, Spirosigmoilina, Cycloforina, Cribromiliolinella, Miliolinella, Miliolina, Lachlanella, Pseudolachlanella, Massilina, Pseudomassilina, Proemassilina, Pseudotriloculina, Sinuloculina, Ptychomiliola, Pseudopyrgo, Pyrgo, Pyrgoella, Quinqueloculina, Parrina, Affinetrina, Triloculina, Triloculinella, Biloculinella, Varidentella, Mesosigmoilina, Sigmoilina, Sigmoilopsis, Sigmoilinella, Siphonaperta, Articulina, Ishamella, Steigerina, Sigmamiliolinella, Spiroloculina, Pseudohauerinella, Vertebralina, Wiesnerella, Ophthalmidium, Edentostomina, Spirophthalmidium, Nodophthalmidium, Nubecularia, Nodobacularia, Peneroplis, Coscinospira, Spirolina, Dendritina, Sorites, Miliammina and Squamulina) (Table 1 and Supplementary Table S1).

The Order Spirillinida is only composed of two families (Spirillinidae and Patellinidae) and two genera (Spirillina and Patellina) (Table 1 and Supplementary Table S1).

The Order Lagenida is represented by only one superfamily (Nodosarioidea), two families (Lagenidae and Nodosariidae) and eight genera (Lagena, Procerolagena, Hyalinonetrion, Reussoolina, Pyramidulina, Dentalina, Nodosaria and Laevidentalina) (Table 1 and Supplementary Table S1).

The Order Vaginulinida includes the family Vaginulinidae and the genus Lenticulina (Table 1 and Supplementary Table S1).

Similarly, the Order Robertinida is solely represented by the superfamily Robertinoidea, the family Robertinidae and the genus Pseudobulimina (Table 1 and Supplementary Table S1). 
The Order Rotaliida encompasses 16 superfamilies (Buliminoidea, Cassidulinoidea, Chilostomelloidea, Fursenkoinoidea, Turrilinoidea, Bolivinoidea, Discorboidea, Discorbinelloidea, Planorbulinoidea, Nonionoidea, Glabratelloidea, Rotalioidea, Acervulinoidea, Asterigerinoidea, Nummulitoidea, and Murrayinellidae), 35 families (Buliminidae, Reussellidae, Trimosinidae, Bolivinitidae, Tortoplectellidae, Siphogenerinoididae, Trichohyalidae, Anomalinidae, Fursenkoinidae, Turrilinidae, Stainforthiidae, Bolivinidae, Rosalinidae, Eponididae, Cancrisidae, Discorbidae, Heleninidae, Discorbinellidae, Pseudoparrellidae, Cibicididae, Planorbulinidae, Cymbaloporidae, Nonionidae, Glabratellidae, Elphidiidae, Elphidiellidae, Haynesinidae, Ammoniidae, Notorotaliidae, Acervulinidae, Amphisteginidae, Epistomariidae, Asterigerinatidae, Nummulitidae and Murrayinellidae) and 66 genera (Bulimina, Reussella, Fijiella, Quirimbatina, Trimosina, Parabrizalina, Sagrinella, Neocassidulina, Euloxostomum, Loxostomina, Pseudobrizalina, Bolivinellina, Tortoplectella, Rectobolivina, Buccella, Riminopsis, Fursenkoina, Floresina, Hopkinsina, Stainforthia, Bolivina, Rosalina, Neoconorbina, Gavelinopsis, Eponides, Poroeponides, Cancris, Valvulineria, Discorbis, Helenina, Discorbinella, Hanzawaia, Facetocochlea, Cibicides, Cibicidoides, Heterolepa, Lobatula, Planorbulina, Planorbulinella, Millettiana, Cymbaloporetta, Cymbaloporella, Pseudononion, Nonion, Nonionella, Pileolina, Protelphidium, Elphidium, Cribroelphidium, Porosononion, Elphidiella, Haynesina, Ammonia, Challengerella, Asterorotalia, Rotalidium, Rotalinoides Pseudorotalia, Cristatavultus, Aceroulina, Amphistegina, Monspeliensina, Eoeponidella, Heterostegina, Operculina and Murrayinella) (Table 1 and Supplementary Table S1).

The Order Polymorphinida includes only one superfamily (Polymorphinoidea), three families (Glandulinidae, Polymorphinidae and Ellipsolagenidae) and nine genera (Glandulina, Globulotuba, Polymorphina, Guttulina, Globulina, Sigmomorphina, Oolina, Buchnerina and Fissurina) (Table 1 and Supplementary Table S1).

The highest benthic foraminiferal similarity is shared between the southern coast and the southern islands $(\beta \mathrm{w}=0.82)$, followed by the northern islands and the Kuwait Bay $(\beta \mathrm{w}=0.84)$ (Table 2).

Table 2. $\beta \mathrm{w}$ diversity values calculated for the northern islands, southern islands, tidal flat southern coast and Kuwait Bay.

\begin{tabular}{|c|c|c|c|c|c|c|c|}
\hline \multicolumn{3}{|c|}{ Global $\beta$ Diversities } & \multirow{2}{*}{$\begin{array}{c}\begin{array}{c}\text { Northern } \\
\text { Island }\end{array} \\
0.00\end{array}$} & \multirow[t]{2}{*}{$\begin{array}{l}\text { Southern } \\
\text { Island }\end{array}$} & \multirow[t]{2}{*}{$\begin{array}{c}\text { Tidal } \\
\text { Flat }\end{array}$} & \multirow[t]{2}{*}{$\begin{array}{c}\text { Southern } \\
\text { Coast }\end{array}$} & \multirow[t]{2}{*}{$\begin{array}{c}\text { Kuwait } \\
\text { Bay }\end{array}$} \\
\hline \multirow{5}{*}{ Whittaker $(\beta w)$} & \multirow{5}{*}{1.12} & Northern Island & & & & & \\
\hline & & Southern Island & 0.84 & 0.00 & & & \\
\hline & & Tidal flat & 1.80 & 1.69 & 0.00 & & \\
\hline & & Southern coast & 0.89 & 0.82 & 1.79 & 0.00 & \\
\hline & & Kuwait Bay & 0.84 & 0.86 & 1.69 & 0.85 & 0.00 \\
\hline
\end{tabular}

On the other hand, the highest dissimilarity is found between the tidal flat and the northern island and the southern coast $\beta w=1.80$ and 1.79 , respectively (Table 2).

\section{Discussion}

The integration of the recognized benthic foraminiferal taxa in the present study from Kuwait Bay and Auha, Failaka and Miskan Islands with those previously recognized in all available records within Kuwait territorial waters leads to the identification of a total of 451 species ( $\gamma$ diversity), belonging to 156 genera, 64 families, 31 superfamilies and 9 orders. These figures, however, would significantly underestimate the real $\gamma$ diversity of benthic foraminifera in Kuwait waters for two main reasons. Most of the benthic foraminiferal studies reported numbers of taxa that were not classified at the species level (sp.) and have been here therefore grouped in a category (genus + spp.). This approximation was necessary given the absence of type materials that has prevented the comparison of the unidentified taxa. As an example, [58], which represents one of the most accurate studies of benthic foraminiferal distribution in Kuwait, reported 42 taxa of Quinqueloculina, of which 13 are assigned at species level, 15 are tentatively assigned (confer, cf.) and 14 are unassigned at species level, so left in open 
nomenclature (sp.); the latter might be higher, as in this case, than $30 \%$. Similarly, [27] suggested that most of the taxa mainly belonging to Quinqueloculina and Triloculina genera retrieved in the Arabian Gulf were reported in open nomenclature. The lack of materials for comparison (i.e., type and reference collection) and of comprehensive taxonomical guides is not solely missing for Kuwait marine areas but also for the Arabian Gulf [27]. Therefore, it is not surprising that several new benthic foraminiferal species (i.e., Falsonubeculina arabica and Pseudotriloculina hottingeri) and genus (Falsonubeculina) have been recently identified in the Gulf [70-72].

Moreover, the Class Monothalamea was not here considered, though it commonly represents a largely diversified group of foraminifera [73], whose diversity is mostly neglected in Kuwait. In fact, to the best of our knowledge, no study has yet relied on or at least considered the soft-shell monothalamids ('allogromiids') in Kuwait marine areas. The only available data are the molecular ones (eDNA metabarcoding) associated with the samples collected in the Kuwait Bay in the present study. On the basis of these data, 94 Molecular Operational Taxonomic Units were recognized, using a filtering $>1000$ reads [74]. The majority of sequences was assigned to two clades of monothalamous foraminifera clade $\mathrm{Y}(26.4 \%)$, abundant in many metabarcoding studies, and a new clade KUW $(22 \%)$, which is reported for the first time here [74]. The third very abundant taxon is an undescribed species of Saccamminidae (20.8\%), closely related to a genotype reported from the North Sea coastal water. Among other monothalamid genera, the most abundant are Vellaria (3.8\%) and an allogromiid sp. (3.3\%) [74]. Monothalamids are commonly ignored by traditional morphological studies, despite dominating the metabarcoding dataset, as in the Kuwait Bay. On the contrary, it is worth mentioning that only a very few studies, i.e., [28,30], and the present data for the Kuwait Bay area are based on the living benthic foraminiferal assemblages. The total assemblages, which are time-averaged assemblages based on the combination of living and dead foraminifera, might include allochthonous taxa that were transported from other localities.

Despite of different factors affecting positively or negatively the estimation of the benthic foraminiferal diversity in Kuwait territorial waters, the here-reported $\gamma(452)$ benthic foraminiferal diversity is relatively high and can be compared to the available records and census data in other basins, such as 799 species in the Aegean Sea [21], 818 species around the Korean peninsula [22], 946 species in the Sahul Shelf and Timor Sea [75], 987 species in the Gulf of Mexico [17] and 1107 species in the northwestern European continental margin [19]. These figures are somewhat higher than those of Kuwait, but it needs to be stressed that the herein considered area, namely Kuwait territorial water, has a limited extension compared to the previous ones (i.e., the Aegean Sea or the Gulf of Mexico). Indeed, the territorial marine waters of Kuwait are characterized by shallow depths, reaching a maximum depth of about $30 \mathrm{~m}$, so most of the deep-water benthic foraminifera are absent. Despite this, Kuwait waters offer a variety of different environments and sub-environments, including the relatively low salinity/muddy areas in the northern part, the embayment (Kuwait Bay), the rocky tidal flats in the southern part, the coral reef systems, the islands and the shelf slope that all together host a larger diversified biota (i.e., benthic foraminifera, macrofauna, zooplankton and phytoplankton).

The Arabian Gulf, the hottest marine environment on Earth, has been recently suggested as a model for the 2100 climate change [2], by which understanding the potential biodiversity loss triggered by the climate changes. Moreover, a differential warming within the Gulf with a more severe SST increase in the northernmost part of the Gulf, including Kuwait, was predicted [4]. These changes concurrently occur with a rapid development and antropogenization of coastal environments that ultimately lead to a deterioration of natural habitats. In light of it, the assessment of the diversity, as well as the understanding of its spatial and temporal changes, is a prerequisite and represents the baseline information for the implementation of natural conservation plans and species protection.

On the basis of the present data, we also revealed that some species, such as Amphistegina lessonii, have only been recently reported in Kuwait [28,58]. Amphisteginids have been reported to extend their geographical distribution in response to increased SST [76,77]. The first record of A. lessonii was found in two stations (15 at $14.6 \mathrm{~m}$ water depth and 33 at $22 \mathrm{~m}$ water depth), collected in 2000, 
around the unique island of Umm al Maradim that represents the largest and southernmost coral island in Kuwait [28]. Later on, it was documented in an offshore carbonate ramp near Qaro cay in one station (K039 at $10.5 \mathrm{~m}$ water depth) collected during an extensive offshore Southern Kuwait sampling campaign in October-December 2001 and in June 2002 [58,78]. Both of these localities, Umm al Maradim Island and Qaro cay are located in the southernmost part of Kuwait, away from the influence of Shatt al-Arab Delta discharge. In fact, Amphistegina is an algal symbiont-bearing large foraminiferal genus thriving in warm, clear, nutrient-poor, shallow environments [76,79], and its distribution within Kuwait waters is likely influenced by the plume generated by the Shatt al-Arab river in the northern area. This plume is deflected by the Coriolis effect that excludes, therefore, most of the Iranian coast [35]. Accordingly, [27] identified two species of Amphistegina, namely A. lessonii and Amphistegina papillosa, in several samples along the Iranian coast. Larger benthic foraminifera are an informal and polyphyletic group of calcifying foraminiferal organisms hosting symbionts (i.e., algae) and significantly contribute to $\mathrm{CaCO}_{3}$ cycling in the ocean [80]. They live within the photic zone and in oligotrophic warm waters. Among the larger benthic foraminifera, only A. lessonii, Assilina/Operculina ammonoides, Assilina/Operculina complanata, Heterostegina depressa, Coscinospira hemprichii, Peneroplis pertusus and Peneroplis planatus have been reported from Kuwait [81]. In addition to them, we here also report Operculina gaimardi, Operculina sp., Heterostegina sp., Peneroplis arietinus, Dendritina rangi, Sorites orbiculus and Sorites marginalis. The most frequent recognized taxa belong to the genus Peneroplis, namely P. arietinus, P. planatus and P. pertusus, and O. complanata, followed by O. ammonoides, O. gaimardi, S. marginalis, and S. orbiculus. Most of these taxa are mainly documented in the southern islands (i.e., Umm Al-Maradim, Qaruh and Kubbar Islands) and the southern coast (Al-Khiran, Khor Iskander and Ras Al-Zour) but are basically scattered around the northern islands (i.e., Failaka Island, Bubiyan Island and the Shatt al-Arab area) or mostly absent within the Kuwait Bay (Supplementary Table S1).

The most abundant wall type, calculated based on the number of the identified species out of the $\gamma$ diversity, is porcelaneous $(48.5 \%)$, followed by hyaline wall type $(42.6 \%)$ and only a minor percentage $(8.9 \%)$ is represented by agglutinated species. The least diversified orders, in terms of genera, are Vaginulinida (one genus), Robertinida (one genus) and Spirillinida (two genera), followed by Lituolida (six genera), Lagenida (six genera) and Textulariida (eight genera). On the other hand, the highest generic diversification is found in the Order Rotaliida, represented by 66 genera, and in the Order Miliolida, including by 54 genera. The most diversified genera within Textulariida is Textularia, accounting for 18 species. On the other hand, Quinqueloculina, Triloculina and Spiroloculina are represented by 58, 24 and 18 species, respectively. Rotaliida are mainly denoted by Elphidium (13 species) and Ammonia (13 species).

When considering the $\beta \mathrm{w}$ diversity index comparing different environments, the highest benthic foraminiferal dissimilarity is identified between the tidal flat and both the northern islands and the southern coast. This might be explained by the different environmental and sedimentological features characterizing the areas. In fact, tidal flats are mostly located in the southern coastal province between the coastal area of Kuwait City and the southern borders with Saudi Arabia and are characterized by relatively thick cover of sand and bounded landward by several oolitic ridges and inland sabkha flats. On the other hand, the submerged estuarine area in the northern part of Kuwait, including the six northern offshore islands (Warba, Bubiyan, Miskan, Failaka, Auha and Umm Al-Namil), represents an extensive mudflat covered by a mixture of fine sand, silt and clay. This area is strongly influenced by the Shatt al-Arab river plume that affects the sedimentary influx in this area and, in turn, the thickness of the photic zone. The shelf slope is located in the central to southern part of the Kuwait coast, and according to [7], it represents a separated physiographic region mostly characterized by rocky substrates. The highest benthic foraminiferal similarity is instead documented between the southern coast and the southern islands, likely due to similar substrate (i.e., less affected by the Shatt al-Arab river plume) and more oligotrophic conditions. Three islands, namely Kubbar, Qaruh and Umm Al-Maradim are characterized by coral reef colonies in the subtidal zones that, in terms of substrate, 
are more similar to the southern coast than to the other physiographic areas, and this might explain the comparable benthic foraminiferal diversity.

\section{Conclusions}

The implementation of natural conservation plans requires an accurate knowledge of the ecosystem, biodiversity and ecosystem services. In light of the current climatic changes at the global scale, and anthropic pressure at a local one, the documentation of the diversity becomes more and more important for species and environmental protection. The Arabian Gulf is known for its unique oceanographical conditions and endemic biota adapted to extreme conditions. In the northwestern part of the Gulf lies Kuwait, which hosts an important part of biodiversity and is also a nursery ground for a number of species. Several previous investigations have documented high diversity of zooplankton and phytoplankton species thriving within the Kuwait territorial waters, but very limited information exists on the overall diversity of benthic foraminifera. On the basis of the integration of publications, reports and theses with new available data, it has been possible to infer the total benthic foraminiferal diversity within Kuwait territorial waters. This new literature survey documents the presence of 451 species belonging to 156 genera, 64 families, 31 superfamilies and 9 orders. These values are relatively high in consideration of the limited extension and the shallow depth of the Kuwait territorial waters. However, these figures are herein considered as underestimated because of the grouping of unassigned species due to the lack of reference collection and materials, as well as the neglection of the soft-shell monothalamids ('allogromiids').

Supplementary Materials: The following are available online at http://www.mdpi.com/1424-2818/12/4/142/s1. Table S1: List of modern benthic foraminiferal species recognized within Kuwait territorial water (the number within square brackets refers to the available records, as in reference; number refers to the location as in Figure 1; latitudinal and longitudinal range, depth interval, assemblages, number of samples, size fraction and sub-environments are also reported). NI: northern island, SI: southern island, TF: tidal flat, SC: southern coast, KB: Kuwait Bay, n.a.: not available, nc: not considered studies for the calculation of $\beta w$. Figure S1: Schematic map of the environments within Kuwait territorial waters: the northern islands (Failaka Island, Bubiyan Island and the Shatt al-Arab area), the southern islands (Umm Al-Maradim, Qaruh and Kubbar Islands), the southern coast (Al-Khiran, Khor Iskander and Ras Al-Zour), and the tidal flat and the Kuwait Bay (modified after [7]).

Author Contributions: Conceptualization, F.F. and E.A.-E.; methodology, F.F. and E.B.; formal analysis, F.F.; investigation, S.K. and E.A.-E.; resources, E.A.-E.; data curation, E.A.-E. and S.K.; writing-original draft preparation, F.F.; writing-review and editing, F.F. and E.B.; supervision, F.F.; project administration, E.A.-E.; funding acquisition, E.A.-E. All authors have read and agreed to the published version of the manuscript.

Funding: This research was funded by the Kuwait Foundation for the Advancement of Sciences and the Kuwait Institute for Scientific Research, grant number EM084K. The APC was funded by the Kuwait Institute for Scientific Research.

Acknowledgments: The authors are very grateful to Kuwait Institute for Scientific Research for the research support. The authors are also very grateful to four anonymous reviewers for their thoughtful and valuable comments that have greatly improved the paper. Authors thank Mohamed Ibrahim (Alexandria University, Egypt) for supervising a partial work in this paper.

Conflicts of Interest: The authors declare no conflict of interest.

\section{References}

1. Khan, N.Y.; Munawar, M.; Price, A.R.G. The Gulf Ecosystem: Health and Sustainability, 1st ed.; Backhuys Publishers: Leiden, The Netherlands, 2002; pp. 1-509.

2. Riegl, B.M.; Purkis, S.J. Coral Reefs of the Gulf: Adaptation to Climatic Extremes in the World's Hottest Sea, 1st ed.; Springer: Dordrecht, The Netherlands, 2012; pp. 1-379.

3. Sheppard, C.; Al-Husiani, M.; Al-Jamali, F.; Al-Yamani, F.; Baldwin, R.; Bishop, J.; Benzoni, F.; Dutrieux, E.; Dulvy, N.K.; Durvasula, S.R.; et al. The Gulf: A young sea in decline. Mar. Pollut. Bull. 2010, 60, 13-38. [CrossRef] [PubMed]

4. Noori, R.; Tian, F.; Berndtsson, R.; Abbasi, M.R.; Naseh, M.V.; Modabberi, A.; Soltani, A.; Kløve, B. Recent and future trends in sea surface temperature across the Persian Gulf and Gulf of Oman. PLoS ONE 2019, 14, e0212790. [CrossRef] 
5. Khan, N.Y. Physical and human geography. In The Gulf Ecosystem: Health and Sustainability, 1st ed.; Khan, N.Y., Munawar, M., Price, A.R.G., Eds.; Backhuys Publishers: Leiden, The Netherlands, 2002; pp. 3-21.

6. Al-Bakri, D. Environmental Assessment of the Intertidal Zone of Kuwait; Kuwait Institute for Scientific Research Report; Kuwait Institute for Scientific Research: Al-Ahmadi, Kuwait, 1984; pp. 1-429.

7. Al-Yamani, F.Y.; Bishop, J.; Ramadhan, E.; Al-Husaini, M.; Al-Ghadban, A.N. Oceanographic Atlas of Kuwait's Waters, 1st ed.; Kuwait Institute for Scientific Research: Al-Ahmadi, Kuwait, 2004; pp. 1-203.

8. Bishop, J.M. History and current checklist of Kuwait's ichthyofauna. J. Arid Environ. 2003, 54, $237-256$. [CrossRef]

9. Al-Yamani, F.Z.; Skryabin, V.A. Identification Guide for Protozoans from Kuwait's Waters. Coastal Planktonic Ciliates: I. Tintinnids, 1st ed.; Kuwait Institute for Scientific Research: Al-Ahmadi, Kuwait, 2006; pp. 1-109.

10. Al-Yamani, F.Z.; Saburova, M.A. Illustrate Guide on the Flagellates of Kuwait's Intertidal Soft Sediments, 1st ed.; Kuwait Institute for Scientific Research: Al-Ahmadi, Kuwait, 2010; pp. 1-197.

11. Al-Yamani, F.Z.; Prusova, I. Common Copepods of the Northwestern Arabian Gulf: Identification Guide, 1st ed.; Kuwait Institute for Scientific Research: Al-Ahmadi, Kuwait, 2003; pp. 1-162.

12. Al-Kandari, M.; Al-Yamani, F.Y.; Al-Rifaie, K. Marine Phytoplankton Atlas of Kuwait's Waters, 1st ed.; Kuwait Institute for Scientific Research: Al-Ahmadi, Kuwait, 2009; pp. 1-354.

13. Murray, J.W. Ecology and Applications of Benthic Foraminifera, 2nd ed.; Cambridge University Press: Cambridge, UK, 2006; pp. 1-426.

14. Lee, J.L.; Anderson, O.R. Symbiosis in Foraminifera. In Biology of Foraminifera; Lee, J.L., Anderson, O.R., Eds.; Elsevier Science Publishing Co. Inc.: San Diego, CA, USA, 1991; pp. 157-220.

15. Moodley, L.; Middelburg, J.J.; Boschker, H.T.S.; Duineveld, G.; Pel, R.; Herman, P.M.J.; Heip, C.H.R. Bacteria and Foraminifera: Key players in a short-term deep-sea benthic response to phytodetritus. Mar. Ecol. Prog. Ser. 2002, 236, 23-29. [CrossRef]

16. Jorissen, F.J. Benthic foraminifera from the Adriatic Sea; principles of phenotypic variation. Utrecht Micropaleontol. Bull. 1988, 37, 1-174.

17. Sen Gupta, B.K.; Smith, L.E. Modern Benthic Foraminifera of the Gulf of Mexico: Census report. J. Foraminifer. Res. 2010, 40, 247-256. [CrossRef]

18. Milker, Y.; Schmiedl, G. A taxonomic guide to modern benthic shelf foraminifera of the western Mediterranean Sea. Palaeontol. Electron. 2012, 15, 1-134. [CrossRef]

19. Dorst, D.; Schönfeld, J. Diversity of benthic Foraminifera on the shelf and slope of the NE Atlantic: Analysis of datasets. J. Foraminifer. Res. 2013, 43, 238-254. [CrossRef]

20. Martins, M.V.; Frontalini, F.; Laut, L.L.; Silva, F.S.; Moreno, J.; Sousa, S.; Zaaboub, N.; El Bour, M.; Rocha, F. Foraminiferal Biotopes and their Distribution Control in Ria de Aveiro (Portugal): A multiproxy approach. Environ. Monit. Assess. 2014, 186, 8875-8897. [CrossRef]

21. Frontalini, F.; Kaminski, M.A.; Mikellidou, I.; du Châtelet, E.A. Checklist of benthic foraminifera (class Foraminifera: D’Orbigny 1826; phylum Granuloreticulosa) from Saros Bay, northern Aegean Sea: A biodiversity hotspot. Mar. Biodivers. 2015, 45, 549-567. [CrossRef]

22. Kim, S.; Frontalini, F.; Martins, M.V.; Lee, W. Modern benthic foraminiferal diversity in Jeju Island and first insights into the total diversity of Korea. Mar. Biodivers. 2016, 46, 337-354. [CrossRef]

23. Cherif, O.H.; Al-Ghadban, A.N.; Al-Rifaiy, I.A. Distribution of foraminifera in the Arabian Gulf. Micropaleontology 1997, 43, 253-280. [CrossRef]

24. Arslan, M.; Kaminski, M.A.; Tawabini, B.S.; Ilyas, M.; Babalola, L.O.; Frontalini, F. Seasonal variations, environmental parameters and standing crop assessment of benthic foraminifera in eastern Bahrain. Arabian Gulf. Geol. Q. 2016, 60, 24-35. [CrossRef]

25. Arslan, M.; Kaminski, M.A.; Tawabini, B.S.; Ilyas, M.; Frontalini, F. Benthic foraminifera in sandy (siliciclastic) coastal sediments of the Arabian Gulf (Saudi Arabia): A technical report. Arab. J. Geosci. 2016, 9, 7. [CrossRef]

26. Amao, A.O.; Kaminski, M.A.; Qurban, M.A.; Thadikal, J.; Frontalini, F. A baseline investigation of benthic foraminifera in relation to marine sediments parameters in western parts of the Arabian Gulf. Mar. Pollut. Bull. 2019, 146, 751-766. [CrossRef] [PubMed]

27. Amao, A.O.; Kaminski, M.A.; Asgharian Rostami, M.; Gharaie, M.H.M.; Lak, R.; Frontalini, F. Distribution of benthic foraminifera along the Iranian Coast. Mar. Biodivers. 2019, 49, 933-946. [CrossRef]

28. Al-Enezi, E.; Al-Ghadban, A.N.; Al-Refai, I.; Pieretti, N.; Frontalini, F. Living benthic foraminifera around the unique Umm al Maradim Island (Kuwait). Kuwait J. Sci. 2019, 46, 59-66. 
29. Al-Zamel, A.; Al-Sarawi, M.; Khader, S.; Al-Rifaiy, I. Benthic foraminifera from polluted marine environment of Sulaibikhat Bay (Kuwait). Environ. Monit. Assess. 2009, 149, 395-409. [CrossRef]

30. Al-Enezi, E.; Frontalini, F. Benthic foraminifera and environmental quality: The case study of Sulaibikhat Bay (Kuwait). Arab. J. Geosci. 2015, 8, 8527-8538. [CrossRef]

31. Neelamani, S.; Al-Salem, K.; Rakha, K. Extreme waves for Kuwaiti territorial waters. Ocean Eng. 2007, 34 , 1496-1504. [CrossRef]

32. Al-Bakri, D.; El-Sayed, M.I. Mineralogy and provenance of the elastic deposits of the modern intertidal environment of the northern Arab. Gulf. Mar. Geol. 1991, 97, 121-135. [CrossRef]

33. Kassler, P. The structural and geomorphic evolution of the Persian Gulf. In The Persian Gulf. Holocene Carbonate Sedimentation and Diagenesis in a Shallow Epicontinental Sea, 1st ed.; Purser, B.H., Ed.; Springer: Berlin, Germany, 1973; pp. 11-32.

34. Al-Sarawi, M.A.; Gundlach, E.; Baca, B.J. Coastal geomorphology and resources in terms of sensitivity to oil spill in Kuwait. J. Univ. Kuwait (Sci.) 1988, 15, 141-184.

35. Riegl, B.; Poiriez, A.; Janson, X.; Bergman, K.L. The gulf: Facies belts, physical, chemical, and biological parameters of sedimentation on a carbonate ramp. In Carbonate Depositional Systems: Assessing Dimensions and Controlling Parameters, 1st ed.; Westphal, H., Riegl, B., Eberli, G.P., Eds.; Springer Science \& Business Media: New York, NY, USA, 2010; pp. 145-213.

36. Khalaf, F.; Al-Bakri, D.; Al-Ghadban, A. Sedimentological characteristics of the surficial sediments of the Kuwaiti marine environment, northern Arabian Gulf. Sedimentology 1984, 31, 531-545. [CrossRef]

37. Reynolds, R.M. Physical oceanography of the Gulf, Strait of Hormuz, and the Gulf of Oman-Results from the Mt Mitchell expedition. Mar. Pollut. Bull. 1993, 27, 35-59. [CrossRef]

38. Jones, D.A.; Price, A.R.G.; Al-Yamani, F.Y.; Al-Zaidan, A. Coastal and marine ecology. In The gulf Ecosystem: Health and Sustainability, 1st ed.; Khan, N.Y., Munawar, M., Price, A.R.G., Eds.; Backhuys Publishers: Leiden, The Netherlands, 2002; pp. 65-103.

39. Peiris, N.I. Recent Foraminifera and Ostracoda from the Persian Gulf. Master's Thesis, University College of Wales, Aberystwyth, UK, 1969.

40. Anber, S.A. Foraminifera from the Offshore Area of Kuwait (Northern Arabian Gulf). Master's Thesis, Kuwait University, Kuwait City, Kuwait, 1974.

41. Shublaq, W. Foraminiferida from Bottom Sediments in the Northwestern Part of the Arabian Gulf (Offshore Kuwait and Saudi Arabia-Kuwait Portioned Zone). Master's Thesis, Kuwait University, Kuwait City, Kuwait, 1977.

42. Al-Abdul Razzaq, S.; Khalaf, F.; Al-Bakri, D.; Shublaq, W.; Al-Sheikh, Z. Marine Sedimentology and Benthic Ecology of Kuwait Environment; Report No. KISR 694; Kuwait Institute for Scientific Research: Al-Ahmadi, Kuwait, 1982.

43. Al-Abdul Razzaq, S.; Shublaq, W.; Al-Sheikh, Z. The marine benthic microfauna of the tidal flats of Kuwait. J. Kuwait Univ. 1983, 10, 101-109.

44. Al-Abdul-Razzaq, S.; Bhalla, S. On the genus Cribrospirlina Haman, 1972 (Foraminifera). J. Micropaleontol. 1987, 6, 63-64. [CrossRef]

45. Al-Abdul-Razzaq, S.; Bhalla, S. Microfauna from Al-Khiran area, Southern Kuwait. Rev. Paléobiol. 1987, 6, 139-142.

46. Shublaq, W. Microfauna of Kuwait's Marine Environment (Foraminifera and Ostracoda); Phase I. Final Report, Restricted, EES-108; Reports No. KISR 2812; Kuwait Institute for Scientific Research: Al-Ahmadi, Kuwait, 1988.

47. Al-Zamel, A.; Cherif, O.; Al-Rifaiy, I. Tidal creeks foraminiferal distribution in Khor Al-Mufateh and Khor Al-Malaha, Khiran area, southeast Kuwait. Rev. Micropalaeontol. 1996, 39, 3-26.

48. Al-Shuaibi, A.A.; Cherif, O.H.; Al-Sarawi, M.A. Recent Subtidal Foraminiferal Distribution and Water Quality of Kubbar Island, Kuwait. Master's Thesis, Kuwait University, Kuwait City, Kuwait, 1997.

49. Khader, S. Coastal Geomorphology and Environmental Assessment of Sulaibikhat Bay. Master's Thesis, Kuwait University, Kuwait City, Kuwait, 1997, unpublished.

50. Al-Zamel, Z.; Cherif, O. Subtidal foraminiferal assemblages of the western part of the Shatt Al-Arab Delta, Kuwait, Arabian Gulf. J. Foraminifer. Res. 1998, 28, 327-344. [CrossRef] 
51. Al-Ghadban, A.N. The Potential Impact of Draining the Southern Iraqi Marshes on the Sediment Budget and Associated Pollutants in the Northern Arabian Gulf; Kuwait Institute for Scientific Research: Al-Ahmadi, Kuwait, 2000; pp. 1-230.

52. Al-Enezi, E.H. Environmental Factors Controlling the Distribution of Foraminifera in the Umm Al-Maradem Island and Khor Iskandar Southern Part of Kuwait. Master's Thesis, Kuwait University, Kuwait City, Kuwait, 2002.

53. Al-Kandari, A.J.H. Trace Metals Concentration and Their Effects on Foraminifera at Coastal Area Adjacent to Kuwait University Campus at Shuwaikh. Master's Thesis, Kuwait University, Kuwait City, Kuwait, 2008.

54. Al-Ammar, M. Distribution of Recent Benthic Foraminifera around the Coral Reefs of Quran Island, Southern Kuwait: Variability and Biodiversity. Master's Thesis, Kuwait University, Kuwait City, Kuwait, 2011.

55. Al Theyabi, N.T. Effect of Thermal Pollution on Microfauna "Foraminifera" a Case Study of Ras Al-Zour and Ras Al-Subiya Power Stations, State of Kuwait. Master's Thesis, Kuwait University, Kuwait City, Kuwait, 2012.

56. Uddin, S.; Al-Ghadban, A.N.; Pokavanich, T.; Al Banna, K.; Al-Enezi, E.; Karam, Q.; Al-Shamroukh, D.; Al-Khabbaz, A.; Al- Yaegoub, A. Marine Survey and Dispersion Modeling for Environmental Aspect at MAA and MAB Refineries; Technical Report No. KISR 11496; Kuwait Institute for Scientific Research: Safat, Kuwait, 2013.

57. Nabavi, S.M.B.; Moosapanah, S.G.R.; Ghatrami, E.R.Z.; Ashrafi, M.G.; Nabavi, S.N. Distribution, Diversity and Abundance of Benthic Foraminifera of the Northwestern Persian Gulf. J. Persian Gulf (Mar. Sci.) 2014, 5, 15-26.

58. Parker, J.H.; Gischler, E. Modern and relict foraminiferal biofacies from a carbonate ramp, offshore Kuwait, northwest Persian Gulf. Facies 2015, 61, 1-22. [CrossRef]

59. Khader, S. Benthic Foraminifera Response to Environmental Stress around Three Northern Kuwaiti Islands (Failaka, Auha and Miskan Islands), NW Kuwait, Arabian Gulf. Ph.D. Thesis, Alexandria University, Alexandria, Egypt, 2020, unpublished.

60. Loeblich, A.R.; Tappan, H. Foraminiferal Genera and Their Classification; Van Nostrand Reinhold: New York, NY, USA, 1987; pp. 1-970.

61. Cimerman, F.; Langer, M.R. Mediterranean Foraminifera; Slovenska Akademija Znanosti in Umetnosti, Akademia Scientiarium et Artium Slovenica: Ljubljana, Slovenia, 1991; Volume 30, pp. 1-119.

62. Hottinger, L.; Halicz, E.; Reiss, Z. Recent Foraminifera from the Gulf of Aqaba, Red Sea, 1st ed.; Slovenska Akademija Znanosti Umetnosti: Ljubljana, Slovenia, 1993; pp. 1-179.

63. Sgarella, F.; Moncharmont Zei, M. Benthic foraminifera of the Gulf of Naples (Italy): Systematics and autoecology. Bull. Soc. Paleontol. Ital. 1993, 32, 145-264.

64. Jones, R.W. The Challenger Foraminifera, 1st ed.; Oxford University Press: Oxford, UK, 1994; pp. 1-149.

65. Debenay, J.P. A Guide to 1,000 Foraminifera from Southwestern Pacific, New Caledonia, 1st ed.; IRD, Ed.; Publications Scientifiques du Museum; Museum National d'Histoire Naturelle: Paris, France, 2013; pp. 1-384.

66. Amao, A.O. Benthic Foraminiferal Taxonomy, Distribution and Ecology in the Arabian Gulf. Ph.D. Thesis, King Fahd University of Petroleum and Minerals, Dhahran, Saudi Arabia, 2016.

67. World Register of Marine Species. Available online: http://www.marinespecies.org/aphia.php? $p=$ taxdetails\& id $=1410$ (accessed on 14 February 2020).

68. Hammer, Ø.; Harper, D.A.T.; Ryan, P.D. PAST: Paleontological statistics software package for education and data analysis. Palaeontol. Electron. 2001, 4, 9.

69. Whittaker, R.H. Vegetation of the Siskiyou mountains, Oregon and California. Ecol. Monogr. 1960, 30, 279-338. [CrossRef]

70. Amao, A.O.; Kaminski, M.A. A new foraminiferal species Pseudotriloculina hottingeri n. sp. from the Arabian Gulf. J. Foraminifer. Res. 2017, 47, 366-371. [CrossRef]

71. Amao, A.O.; Kaminski, M.A. Pseudonubeculina arabica n. gen. n. sp., a new Holocene benthic foraminifer from the Arabian Gulf. Micropalaeontology 2016, 62, 81-86.

72. Amao, A.O.; Kaminski, M.A. Falsonubeculina, a replacement name for Pseudonubeculina Amao and Kaminski 2016 (preoccupied). Micropaleontology 2019, 65, 544. 
73. Lecroq, B.; Lejzerowicz, F.; Bachar, D.; Christen, R.; Esling, P.; Baerlocher, L.; Østerås, M.; Farinelli, L.; Pawlowski, J. Ultra-deep sequencing of foraminiferal microbarcodes unveils hidden richness of early monothalamous lineages in deep-sea sediments. Proc. Natl. Acad. Sci. USA 2011, 108, 13177-13182. [CrossRef]

74. Al-Enezi, E.; Al-Hazeem, S. Benthic Foraminifera as Proxies for the Environmental Quality Assessment of the Kuwait Bay: Morphological and Environmental DNA Approaches; Technical report KISR No. EM084C; Kuwait Institute of Scientific Research: Safat, Kuwait, 2019.

75. Loeblich, A.R.; Tappan, H. Foraminifera of the Sahul Shelf and Timor Sea. Cushm. Found. Foram. Res. Spec. Publ. 1994, 31, 1-661.

76. Langer, M.R.; Weinmann, A.E.; Lötters, S.; Bernhard, J.M.; Rödder, D. Climate-driven range extension of Amphistegina (Protista, Foraminiferida): Models of current and predicted future ranges. PLoS ONE 2013, 8, e54443. [CrossRef]

77. Guastella, R.; Marchini, A.; Caruso, A.; Cosentino, C.; Evans, J. "Hidden invaders" conquer the Sicily Channel and knock on the door of the Western Mediterranean Sea. Estuar. Coast. Shelf Sci. 2019, 225, 106234. [CrossRef]

78. Gischler, E.; Lomando, A.J. Offshore sedimentary facies of a modern carbonate ramp, Kuwait, northwestern Arabian-Persian Gulf. Facies 2005, 50, 443-462. [CrossRef]

79. Triantaphyllou, M.V.; Dimiza, M.D.; Koukousioura, O.; Hallock, P. Observations on the life cycle of the symbiont-bearing foraminifer Amphistegina lobifera Larsen, an invasive species in coastal ecosystems of the aegean sea (Greece, E. Mediterranean). J. Foraminifer. Res. 2012, 42, 143-150. [CrossRef]

80. Langer, M.R. Assessing the contribution of foraminiferan protists to global ocean carbonate production. J. Eukaryot. Microbiol. 2008, 55, 163-169. [CrossRef] [PubMed]

81. Förderer, M.; Rödder, D.; Langer, M.R. Patterns of species richness and the center of diversity in modern Indo-Pacific larger foraminifera. Sci. Rep. 2018, 8, 8189. [CrossRef] [PubMed]

(C) 2020 by the authors. Licensee MDPI, Basel, Switzerland. This article is an open access article distributed under the terms and conditions of the Creative Commons Attribution (CC BY) license (http://creativecommons.org/licenses/by/4.0/). 